\title{
Front Matter: Volume 6539
}

, "Front Matter: Volume 6539," Proc. SPIE 6539, Biometric Technology for Human Identification IV, 653901 (12 April 2007); doi: 10.1117/12.732598

SPIE Event: Defense and Security Symposium, 2007, Orlando, Florida, United SPIE. States 


\title{
PROCEEDINGS OF SPIE
}

\section{Biometric Technology for Human Identification IV}

\author{
Salil Prabhakar \\ Arun A. Ross \\ Editors
}

9-10 April 2007

Orlando, Florida, USA

Sponsored and Published by

SPIE-The International Society for Optical Engineering

Volume 6539

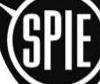

The International Society for Optical Engineering

Proceedings of SPIE-The International Society for Optical Engineering, 9780819466617, v. 6539

SPIE is an international technical society dedicated to advancing engineering and scientific applications of optical, photonic, imaging, electronic, and optoelectronic technologies. 
The papers included in this volume were part of the technical conference cited on the cover and title page. Papers were selected and subject to review by the editors and conference program committee. Some conference presentations may not be available for publication. The papers published in these proceedings reflect the work and thoughts of the authors and are published herein as submitted. The publisher is not responsible for the validity of the information or for any outcomes resulting from reliance thereon.

Please use the following format to cite material from this book:

Author(s), "Title of Paper," in Biometric Technology for Human Identification IV, edited by Salil Prabhakar, Arun A. Ross, Proceedings of SPIE Vol. 6539 (SPIE, Bellingham, WA, 2007) Article CID Number.

ISSN 0277-786X

ISBN 9780819466617

Published by

SPIE-The International Society for Optical Engineering

P.O. Box 10, Bellingham, Washington 98227-0010 USA

Telephone 1 360/676-3290 (Pacific Time) · Fax 1 360/647-1445

http://www.spie.org

Copyright (C) 2007, The Society of Photo-Optical Instrumentation Engineers

Copying of material in this book for internal or personal use, or for the internal or personal use of specific clients, beyond the fair use provisions granted by the U.S. Copyright Law is authorized by SPIE subject to payment of copying fees. The Transactional Reporting Service base fee for this volume is $\$ 18.00$ per article (or portion thereof), which should be paid directly to the Copyright Clearance Center (CCC), 222 Rosewood Drive, Danvers, MA 01923. Payment may also be made electronically through CCC Online at http://www.copyright.com. Other copying for republication, resale, advertising or promotion, or any form of systematic or multiple reproduction of any material in this book is prohibited except with permission in writing from the publisher. The CCC fee code is 0277 $786 \times / 07 / \$ 18.00$.

Printed in the United States of America. 


\section{Contents}

vii Conference Committee

ix Introduction

\section{KEYNOTE PAPERS}

653902 Biometric identification: a holistic perspective (Keynote Paper) [6539-14]

L. D. Nadel, Noblis, Inc. (USA)

653903 Quality dependent fusion of intramodal and multimodal biometric experts (Keynote Paper) [6539-04]

J. Kittler, N. Poh, O. Fatukasi, K. Messer, Univ. of Surrey, Guildford (United Kingdom);

K. Kryszczuk, J. Richiardi, A. Drygajlo, EPFL, IDIAP Research Institute (Switzerland)

\section{SENSING TECHNOLOGY}

653904 Performance analysis of three-dimensional ridge acquisition from live finger and palm surface scans [6539-02]

A. Fatehpuria, D. L. Lau, V. Yalla, L. G. Hassebrook, Univ. of Kentucky (USA)

653905 Robust fingerprint acquisition: a comparative performance study [6539-03]

R. K. Rowe, K. A. Nixon, S. Parthasaradhi, U. Uludag, Lumidigm, Inc. (USA)

653906 3D surface reconstruction and recognition [6539-27]

D. J. Bardsley, L. Bai, Univ. of Nottingham (United Kingdom)

\section{SIGNATURE, HAND, AND EAR}

653907 Classification of handwritten signatures based on name legibility [6539-05]

J. Galbally, J. Fierrez, J. Ortega-Garcia, Univ. Autónoma de Madrid (Spain)

653908 A new approach to hand-based authentication [6539-06]

G. Amayeh, G. Bebis, A. Erol, M. Nicolescu, Univ. of Nevada, Reno (USA)

Pagination: Proceedings of SPIE follow an e-First publication model, with papers published first online and then in print and on CD-ROM. Papers are published as they are submitted and meet publication criteria. A unique, consistent, permanent citation identifier (CID) number is assigned to each article at the time of the first publication. Utilization of CIDs allows articles to be fully citable as soon they are published online, and connects the same identifier to all online, print, and electronic versions of the publication.

SPIE uses a six-digit CID article numbering system in which:

- The first four digits correspond to the SPIE volume number.

- The last two digits indicate publication order within the volume using a Base 36 numbering system employing both numerals and letters. These two-number sets start with $00,01,02,03,04,05,06,07,08,09,0 A, 0 B$... 0Z, followed by 10-1Z, 20-2Z, etc.

The CID number appears on each page of the manuscript. The complete citation is used on the first page, and an abbreviated version on subsequent pages. 
653909 An efficient indexing scheme for binary feature based biometric database [6539-25]

P. Gupta, A. Sana, H. Mehrotra, Indian Institute of Technology Kanpur (India); C. J. Hwang,

Texas State University (USA)

65390A Ear authentication using Log-Gabor wavelets [6539-29]

A. Kumar, The Hong Kong Polytechnic Univ. (Hong Kong China) and Indian Institute of Technology Delhi (India); D. Zhang, The Hong Kong Polytechnic Univ. (Hong Kong China)

\section{FINGERPRINT RECOGNITION}

65390B Using support vector machines to eliminate false minutiae matches during fingerprint verification [6539-07]

P. Mansukhani, S. Tulyakov, V. Govindaraju, Univ. at Buffalo (USA)

65390C Augmenting ridge curves with minutiae triplets for fingerprint indexing [6539-08]

A. Ross, R. Mukherjee, West Virginia Univ. (USA)

65390D Use of ridge points in partial fingerprint matching [6539-09]

G. Fang, S. N. Srihari, H. Srinivasan, P. Phatak, Univ. at Buffalo, SUNY (USA)

65390E A geometric transformation to protect minutiae-based fingerprint templates [6539-10] Y. Sutcu, H. T. Sencar, N. Memon, Polytechnic Univ. (USA)

\section{FACE RECOGNITION I}

65390F Correlation filters for large population face recognition (Invited Paper) [6539-11]

B. V. K. Vijaya Kumar, C. Xie, M. Savvides, Carnegie Mellon Univ. (USA)

$65390 \mathrm{~S}$ Super-resolution for high magnification face images [6539-12]

Y. Yao, B. Abidi, The Univ. of Tennessee (USA); N. D. Kalka, N. Schmid, West Virginia Univ. (USA); M. Abidi, The Univ. of Tennessee (USA)

$65390 \mathrm{H}$ Locality preserving projections as a new manifold analysis approach for robust face superresolution [6539-13]

S. W. Park, M. Savvides, Carnegie Mellon Univ. (USA)

\section{FACE RECOGNITION II}

65390 Robust low dimensional kernel correlation feature spaces that generalize to unseen datasets [6539-17]

R. Abiantun, M. Savvides, B. V. K. Vijaya Kumar, Carnegie Mellon Univ. (USA)

65390J Multi-stream face recognition for crime-fighting [6539-18]

S. A. Jassim, Univ. of Buckingham (United Kingdom); H. Sellahewa, Univ. of Buckingham (United Kingdom) and Gray Cancer Institute (United Kingdom)

65390K Real-time face tracking and pose correction for face recognition using active appearance models [6539-19]

J. Heo, M. Savvides, Carneige Mellon Univ. (USA) 
65390L Template protection and its implementation in 3D face recognition systems [6539-28]

X. Zhou, Fraunhofer IGD (Germany)

\section{STATISTICAL ANALYSIS}

$65390 \mathrm{M}$ Neyman-Pearson biometric score fusion as an extension of the sum rule [6539-15]

J. P. Hube, L-1 Identity Solutions (USA)

$65390 \mathrm{~N}$ Nonparametric statistical data analysis of fingerprint minutiae exchange with two-finger fusion [6539-16]

J. C. WU, M. D. Garris, National Institute of Standards and Technology (USA)

653900 Empirical mode decomposition for removal of specular reflections and cast shadow effects [6539-30]

R. Bhagavatula, M. Savvides, Carnegie Mellon Univ. (USA)

\section{EYE AND BEHAVIORAL BIOMETRICS}

65390P Dissimilarity functions for behavior-based biometrics [6539-20]

R. V. Yampolskiy, V. Govindaraju, Univ. at Buffalo (USA)

65390Q An eye model for uncalibrated eye gaze estimation under variable head pose [6539-22] J. Hnatow, A. Savakis, Rochester Institute of Technology (USA)

Author Index 
Downloaded From: https://www.spiedigitallibrary.org/conference-proceedings-of-spie on 26 Apr 2023

Terms of Use: https://www.spiedigitallibrary.org/terms-of-use 


\title{
Conference Committee
}

\author{
Symposium Chair \\ John C. Carrano, Luminex Corporation (USA) \\ Symposium Cochair
}

Larry B. Stotts, DARPA (USA)

Program Track Chair

Edward M. Carapezza, DARPA (USA) and University of Connecticut (USA)

Conference Chairs

Salil Prabhakar, Digital Persona Inc. (USA)

Arun A. Ross, West Virginia University (USA)

\section{Program Committee}

Behnam Bavarian, Motorola (USA)

Bir Bhanu, University of California, Riverside (USA)

Josef Bigun, Halmstad Universitet (Sweden)

Terrance E. Boult, University of Colorado at Colorado Springs (USA)

James L. Cambier, Iridian Technologies, Inc. (USA)

Jean-Luc E. Dugelay, Institut Eurécom (France)

Patrick J. Flynn, University of Notre Dame (USA)

Jean-Christophe Fondeur, Sagem Morpho Inc. (France)

Venu Govindaraju, SUNY, University at Buffalo (USA)

Patrick J. Grother, National Institute of Standards and Technology (USA)

Vincent Hsu, Identix Inc. (USA)

Anil K. Jain, Michigan State University (USA)

loannis A. Kakadiaris, University of Houston (USA)

Josef Kittler, University of Surrey (United Kingdom)

Stan Z. Li, Chinese Academy of Sciences (China)

David Maltoni, Universitá degli Studi di Bologna (Italy)

James R. Matey, Sarnoff Corporation (USA)

Nicholas Orlans, U.S. Department of Defense Biometrics Fusion Center

(USA) and The MITRE Corporation (USA)

Sharath Pankanti, IBM Thomas J. Watson Research Center (USA)

Jonathon Phillips, National Institute of Standards and Technology (USA)

Sudeep Sarkar, University of South Florida (USA)

Marios Savvides, Carnegie Mellon University (USA)

Michael E. Schuckers, St. Lawrence University (USA)

Diego A. Socolinsky, Equinox Corporation (USA) 
Elham Tabassi, National Institute of Standards and Technology (USA)

Umut Uludag, Lumidigm, Inc. (USA)

B. V. K. Vijaya Kumar, Carnegie Mellon University (USA)

David Zhang, The Hong Kong Polytechnic University (Hong Kong China)

\author{
Session Chairs \\ $1 \quad$ Sensing Technology \\ Salil Prabhakar, Digital Persona Inc. (USA) \\ 2 Keynote Session I \\ Salil Prabhakar, Digital Persona Inc. (USA) \\ 3 Signature, Hand, and Ear \\ Salil Prabhakar, Digital Persona Inc. (USA) \\ $4 \quad$ Fingerprint Recognition \\ Robert K. Rowe, Lumidigm, Inc. (USA) \\ 5 Face Recognition I \\ Arun A. Ross, West Virginia University (USA) \\ $6 \quad$ Keynote Session II \\ Arun A. Ross, West Virginia University (USA) \\ $7 \quad$ Statistical Analysis \\ B. V. K. Vijaya Kumar, Carnegie Mellon University (USA) \\ 8 Face Recognition II \\ Venu Govindaraju, SUNY, University at Buffalo (USA) \\ 9 Eye and Behavioral Biometrics \\ Marios Savvides, Carnegie Mellon University (USA)
}




\section{Introduction}

Positive and reliable automatic identification of humans is a very important topic in a number of law enforcement (e.g., criminal investigation), government (e.g., border control), and commercial (e.g., logical and physical access control) applications. Surrogate representations of identity such as passwords and physical tokens fail to provide a satisfactory level of security in the current electronic era. Biometrics-based authentication techniques utilize physical and behavioral characteristics of individuals (such as fingerprint, iris, and voice) to either verify a claimed identity (biometric verification) or establish the identity of an individual (biometric identification). With increased emphasis on security, there is a growing and urgent need to automatically identify humans both locally and remotely on a routine basis.

The purpose of this conference was to provide a scientific forum for researchers, engineers, system architects, and designers to report recent advances in this important area of human identification using biometrics. The papers presented at this year's conference spanned a variety of biometrics topics with specific emphasis on face recognition and fingerprint recognition topics, which accounted for about half of all the papers. Other topics included hand, signature, ear, eye, and behavioral biometrics as well as statistical methods in fusion.

We were fortunate to have two keynote addresses by prominent figures in the biometrics community. Prof. Josef Kittler of the University of Surrey spoke on the topic of "Quality dependent fusion of intramodal and multimodal biometric experts". Dr. Lawrence Nadel of Noblis, Inc. spoke on the topic of "Biometric identification: a holistic perspective". Biometric systems are being deployed today in real world applications at an unprecedented rate. Industry and academic experts participated in a panel discussion on the timely topic of "Real World Biometrics Deployments". Mr. Daniel B. Nickell, Dr. Robert K. Rowe, and Dr. Marios Savvides, discussed examples of real world biometrics applications, lessons learnt, and challenges that need to be overcome to further accelerate biometrics deployments. This expert panel provided thought provoking insights as well as motivation to researchers and system engineers alike to design biometric systems that are more accurate, robust against attacks, user friendly, and cost effective.

This was the fourth edition of the Biometrics conference hosted by SPIE. The conference has a history of rigorous peer-review, and we are grateful to the researchers for submitting high quality papers. The conference required the authors to submit a six page manuscript for peer review purposes. The program committee comprised of twenty-four area experts and each paper was 
reviewed by two or more experts. We are indebted to the program committee members for providing detailed comments on the submitted papers. We are also thankful to the SPIE staff for their remarkable assistance in organizing the conference. We hope you enjoy reading the compilation of technical papers in this publication.

Salil Prabhakar

Arun Ross 